\title{
Black Lives Matter: Promoting discussion in the English language classroom
}

\author{
Larissa Goulart da Silva \\ University of Warwick \\ Marine Laísa Matte \\ Universidade Federal do Rio Grande do Sul - UFRGS
}

\begin{abstract}
Resumo
Este artigo apresenta um relato de experiência de ensino de Inglês no Programa Idiomas sem Fronteiras. Essa experiência ocorreu no âmbito do Núcleo de Línguas da Universidade Federal do Rio Grande do Sul (UFRGS) e contou com uma prática conjunta de duas professoras. A parceria entre as duas autoras e professoras ocorreu durante o curso Inglês geral com foco em escrita e correção. Por ser um curso de curta duração, desenvolvemos uma unidade didática que pudesse ser utilizada como material ao longo das aulas. A temática escolhida foi o movimento Black Lives Matter (BLM), considerando a necessidade de as aulas de Inglês se aproximarem da realidade do aluno, promovendo discussões relevantes em aula e focando no ensino de escrita, conforme prevê o conteúdo programático do curso. Assim, detalhamos as aulas para refletir acerca de nossa prática enquanto professoras de língua, bem como auxiliar outros professores em suas práticas docentes.
\end{abstract}

Palavras-chave: Ensino de Língua Inglesa; Ensino de escrita; Idiomas sem Fronteiras.

\begin{abstract}
This article presents a report on an experience with English Language teaching practice in the Languages without Borders Programme. This practice happened at the NucLi (center for teaching languages) of the Federal University of Rio Grande do Sul (UFRGS) having two teachers working as partners. The partnership between both teachers occurred during the discipline of English with focus on writing and correction. Taking into account that it is a short course, we developed a didactic unit that could be used as our pedagogical material throughout the classes. Therefore, in accordance with the syllabus of the course, English classes must fit into students' reality; promote relevant discussions in class; and focus on the writing practice. We chose as a theme for our pedagogical unit the Black Lives Matter movement $(B L M)$. Hence, we detail the classes in order to reflect on our own practice as language teachers, as well as to help other teachers in their teaching experiences.
\end{abstract}

Keywords: English Language teaching; Writing practice; Languages without Borders.

\section{INTRODUCTION}

In 2016, the release of the video clip Formation by Beyoncé once again revived the debate about how black people are treated by figures of authority in the United States. This 
discussion soon received media attention encouraging more African-Americans to come forward and report their experiences with racism in different layers of society. Black Lives Matter (BLM), which was already a well-organized movement, gained more evidence in the media, making this debate meaningful not only for the American context, but also for the discussion about race worldwide. Since then, a number of articles have been published in English discussing the role of race in our society, and when we started to teach the discipline of English with focus on writing and correction at the Languages without Borders Programme this was one of the main issues being debated in our students' context. Therefore, taking into consideration that "the foreign language classes should create an environment in which students can engage in activities that demand the use of language based on relevant themes to their contexts and based on several discursive genres" (SCHLATTER, 2009, p. 12), we decided to address this issue in our classes. Thus, we developed a project that encouraged students to discuss the movement Black Lives Matter, and relate these reports about racism in America with their context and their experiences in Brazil.

The aim of this paper is to present the project we developed for this discipline, and to describe how we put it into practice. Hence, this paper is divided into five sections. In the next section, we describe the Languages without Borders Programme, which is the context where we used this material; the following section presents the theoretical background that guided our practice; in section four we describe how the project was developed in class, and in the last section we conclude with some insights for other teachers who might want to address this theme in their classes, and comments about how we worked together.

\section{THE TEACHING CONTEXT}

The aim of this section is to provide a brief contextualization of the Languages without Borders (LwB) Programme and the discipline in which the project was put into practice. LwB is a Brazilian Federal government policy present in 63 universities around Brazil. The programme has two main objectives: the first one is to promote the internationalization of federal universities through English teaching, focusing on academic English. Hence, the target audience of these courses is the academic community, namely, students (undergraduate and graduate), professors and administrative staff of federal universities. The second objective is to promote teacher training, by integrating theory and practice. Thus, the programme offers weekly pedagogical meetings for its teachers. In these meetings, teachers can present their lesson plans, discuss classroom issues or attend workshops related to teaching. Teachers at the LwB programme must be studying to obtain a 
degree in English language teaching or have already graduated from this course. They also need to provide evidence of advanced English proficiency - $\mathrm{C} 1$ according to the CEFR (Common European Framework of Reference for Languages). In order for students to enroll at LwB classes, they have to do a levelling test, which is the TOEFL ITP, and, according to their grades, they are placed in a level corresponding to the CEFR.

The LwB offers English courses with different aims and durations, for instance, the courses can range from 16 hours to 64 hours; nevertheless, all the courses have four hours of classes per week. The project described in this paper was developed by two teachers in the discipline of English with focus on writing and correction at LwB - UFRGS. This is a 16h intensive English course, in which the classes occurred in the period of one month. It is worth mentioning that, although we developed the materials for this course together, we had two different groups, so each of us put the materials in practice in our own classroom. Furthermore, we chose to work collaboratively in order to be more critical about the tasks developed, and to have more input on the outcome of the project. The students in this discipline were undergraduate or graduate students from different areas of expertise who had achieved B1 in their TOEFL ITP results.

The aim of this section was to present the context in which we have developed and put into practice this project. In the next section, we will discuss the theoretical background that supported our practice.

\section{DEVELOPING THE MATERIAL}

In our practice, we adopted a project-based methodology. According to Hernandez (2004), a project is an open format for questioning; it is designed around a theme or a problem that affects us and it should help us to transform information into knowledge. Therefore, we structured our classes in order to give tools for students to produce a final outcome in which they would transform this information discussed in class into knowledge. We asked the students to write an opinion article about racism and how race was perceived in Brazil after discussing this theme in class. Barbosa $(2004$, p.10) also examines the roles of projects in the classroom. This author argues that "projects are created and executed so students can learn how to study, research, look for information, be critical, doubt, argue and think" ${ }^{\text {. In our }}$ experience, this was a very important aspect of project-based learning. The project should

\footnotetext{
${ }^{1}$ This and all the ensuing translations were made by the authors. The original in Portuguese: "os projetos são elaborados e executados para aprender a estudar, a pesquisar, a procurar informações, a exercer a crítica, a duvidar, a argumentar, a opinar, a pensar."
} 
encourage students to learn how to learn and to reflect critically about the knowledge being acquired.

Furthermore, even though we are English teachers, it is our understanding that the language classes should not focus only on linguistic features, but rather integrate language and other disciplines, so as to make the classes more meaningful. Barbosa (2004, p.08) corroborates this view when she mentions that "in this new way of producing science the disciplines start to share their common goals and expand their barriers in order to address themes in their complexities." ${ }^{2}$ Our first decision in this project was to select a theme that was relevant to our students and, after that, to select a discourse genre that our students would produce by the end of the project. The final outcome of this project was an opinion article in English which would circulate among other students taking this discipline.

The table below depicts the first decisions we carried out regarding our project.

\footnotetext{
${ }^{2}$ Original: "Nesse novo modo de produzir a ciência as disciplinas passam a compartilhar objetivos comuns e expandem suas fronteiras em função de abordar os temas em sua complexidade."
} 
Table 01 - Steps of the project

\begin{tabular}{|c|c|}
\hline Theme & Racism and manifestations \\
\hline $\begin{array}{l}\text { Research questions } \\
\text { (questions that will guide the } \\
\text { project) }\end{array}$ & $\begin{array}{l}\text { What is the importance of movement like Black Lives } \\
\text { Matter in the USA? } \\
\text { What other forms of protest occur besides } \\
\text { manifestations? } \\
\text { How do the manifestations of the movement Black } \\
\text { Lives Matter relate to movements in Brazil? }\end{array}$ \\
\hline $\begin{array}{l}\text { Sources } \\
\text { (materials discussed in class) }\end{array}$ & $\begin{array}{l}\text { Videoclip Formation - Beyoncé } \\
\text { Opinion article Ivy League professor: :I would much } \\
\text { rather my own children interact with drugs than with } \\
\text { the police - Carl L. Hart }\end{array}$ \\
\hline $\begin{array}{l}\text { Outcome } \\
\text { (a text that the students will } \\
\text { write by the end of the project) }\end{array}$ & Opinion article \\
\hline $\begin{array}{l}\text { Support genres } \\
\text { (genres that we have used in } \\
\text { the project) }\end{array}$ & $\begin{array}{l}\text { Comments; } \\
\text { Videoclips; } \\
\text { Opinion article. }\end{array}$ \\
\hline $\begin{array}{l}\text { Steps for the implementation } \\
\text { of the project } \\
\text { (sequence of tasks that } \\
\text { compose the project) }\end{array}$ & $\begin{array}{l}\text { Discussion about Formation; } \\
\text { Research cases of racism in Brazil; } \\
\text { Read an opinion article by a black professor at } \\
\text { university; } \\
\text { Relate personal experience with cases of racism } \\
\text { reported in the media. } \\
\text { Discussed further details in Table } 02\end{array}$ \\
\hline Publication & Create a booklet and share with the other group \\
\hline
\end{tabular}

A project is composed of a sequence of tasks. Nunan (2004) defines pedagogical tasks as

\footnotetext{
a piece of classroom work that involves learners in comprehending, manipulating, producing or interacting in the target language while their attention is focused on mobilizing their grammatical knowledge in order to express meaning, and in which the intention is to convey meaning rather than to manipulate form. (NUNAN, 2004, p.02)
}

When developing our project we aimed at designing the tasks based on real uses of English. Therefore, we used the texts, both written and oral, as the centre of the work with language, and by the end of each class students had a piece of writing related to the goals of 
the project. We also took into account what the Referenciais Curriculares do Rio Grande do Sul (hereafter, RCs) state as the purpose of language classes, which is "to extend the scope and the the quality of the experience the learners have with various signs of language, contributing to a broader and more significant participation in the variety of cultures they are part of 3 (2009, p. 55). Furthermore, we agree with Pinter (2007, p.190) when this author argues that "tasks encourage learners to communicate with each other in real time," and, as teachers, it was important for us to promote learner-learner interaction since this promotes effective learning (Vygotsky, 1984; Lantolf, 2000). Finally, we took into consideration students' objectives and needs, focusing on linguistic resources that would be relevant for their written production by the end of the project.

The table below describes the sequence of tasks used in this project.

\footnotetext{
3 "ampliar o alcance e a qualidade da experiência dos educandos com diferentes manifestações da linguagem, contribuindo para que tenham uma participação mais ampla e significativa nas variadas culturas das quais fazem parte" (RCs, 2009, p.55)
} 
Table 02 - Descriptions of the tasks

\begin{tabular}{|c|c|c|}
\hline Task & Text & Content and ability \\
\hline Introducing the topic & $\begin{array}{l}\text { Videoclip Formation by } \\
\text { Beyoncé }\end{array}$ & $\begin{array}{l}\text { Vocabulary related to the lyrics; } \\
\text { Historical context referenced in the } \\
\text { video; } \\
\text { Cases of racism in Brazil. }\end{array}$ \\
\hline $\begin{array}{l}\text { Understanding the } \\
\text { theme and working } \\
\text { with the genre. }\end{array}$ & $\begin{array}{l}\text { Ivy League professor: 'I } \\
\text { would much rather my own } \\
\text { children interact with drugs } \\
\text { than with the police' }\end{array}$ & $\begin{array}{l}\text { Vocabulary related to the theme of } \\
\text { the text; } \\
\text { Synonyms to avoid repetition; } \\
\text { Conjunctions to connect ideas in } \\
\text { the text; } \\
\text { Structure of the genre. }\end{array}$ \\
\hline Understanding the text & $\begin{array}{l}\text { Ivy League professor: 'I } \\
\text { would much rather my own } \\
\text { children interact with drugs } \\
\text { than with the police' }\end{array}$ & $\begin{array}{l}\text { Cases of racism in Brazil that } \\
\text { relate to the situation described in } \\
\text { the text; } \\
\text { Conjunctions to connect ideas in } \\
\text { the text; } \\
\text { Structure of the genre; } \\
\text { Order of the ideas presented; } \\
\text { Written production of their first } \\
\text { version of the text. }\end{array}$ \\
\hline Reviewing & Their own text & $\begin{array}{l}\text { Revision of the text based on the } \\
\text { comments made by the colleagues } \\
\text { and the teachers. Write the final } \\
\text { version of the text. }\end{array}$ \\
\hline
\end{tabular}

The aim of this section was to present our understanding of projects and tasks, as these two concepts guided the development of our pedagogical materials. We also introduced in details the sequence of tasks that compose our project. In the next section, we will report how this was put into practice in the classroom.

\section{DESCRIBING THE CLASSES}

Taking into account that our project was developed during four classes, in this section we are going to give an individual description of each of these classes, with emphasis in what was required from students.

In the first class, we introduced the theme of our project by showing the students Beyoncé's videoclip Formation. Before watching the video, students discussed the following questions in groups: 


\title{
a) Do you usually listen to the radio? What kind of songs do you prefer? \\ b) Who is Beyoncé? What do you know about her? \\ c) Do you know any of her songs? Which ones?
}

\begin{abstract}
After the discussion, we worked with the most frequent words in the song, giving other words and definitions for students to connect and understand their meaning. After these pre-reading activities we watched the video clip. Based on the video, we discussed the historical references in the song as it brings up several elements of United States history. At the end of the class, we asked the students to relate the theme of the song with cases of prejudice that they had witnessed, and we encouraged them to write a report on a specific case.
\end{abstract}

We started the second class by discussing with the students their perceptions on different ways black people and white people are treated in society, and the role of the police in protecting individuals, as this related to the text we were going to discuss. We started with the following questions:

a) What do you think about the role of the police nowadays?

b) Are they in charge of protecting our lives? If so, why are there so many people killed every day?

c) Think of 3 words that characterize the way white and black people are treated in our society. Later, explain your choices.

Next, we worked with expressions and word clusters that were relevant for the understanding of the text Ivy League professor: 'I would much rather my own children interact with drugs than with the police'. We also asked them to suggest synonyms for the less frequent expressions in the text. Later, we highlighted some passages in the text where conjunctions appeared and we worked with these words, as they would be an essential topic for their final writing. We finished this class by reading the text as a group, having some students volunteering for reading a specific paragraph out loud. One of the negative aspects of this class is that we did not anticipate that students would have problems understanding the text; even though they were B1 level, they had difficulties with sentence structure and 
associating the meaning of the connectors with the message in the text. It was our intention to ask students to write the first version of their text this class, but it was not possible, as we had to do more exercises focused on reading comprehension. At the end of this class, we asked the students to make a small study of research on cases of racism in Brazil and to report them in the beginning of the following class.

In the third class, we resumed the discussions of the previous meetings, listened to the students' reports, and we returned to the reading of the text itself. After that, as students had problems understanding the text before, we prepared some exercises to check their comprehension of the text. We proposed an activity in which the students had to put the facts narrated in the text in order. In this same class, another discussion task was done, in which the students gave their opinions on the main arguments addressed in the text by relating them to their own reality. Before the end of the class, we requested students to write in class a first version of their opinion article.

The fourth and last class was focused on students' second version of their written production based on the comments we made on every text. At the beginning of the class, we asked students to read and comment on their colleagues' text. This way students would have more insights into what aspects to improve in their opinion articles. Furthermore, their colleagues might know a different argument that would make their texts stronger. For the production of the texts, the students could rely on concrete examples experienced by them or examples that had been discussed in class; they should express their opinion regarding different expressions of the $B L M$ movement in Brazil. The final version of the text was given to us and, after the classes had finished, we prepared a booklet that was shared with students from the other groups.

\section{FINAL CONSIDERATIONS}

We consider that this experience of developing materials together was productive for us and also for our" students as they could share their written texts with students outside their classrooms. Furthermore, students had contact with a theme that, although being close to their reality, might not have been so widely discussed if they only had access to texts in Portuguese. In addition, their written production in English allows them to participate in a broader discussion regarding this issue not only with Brazilians, but with people who are concerned about racism worldwide. 
As stated before, the theme of the discipline was Black Lives Matter having in mind that language classes must fit into students' realities. Moreover, the relevance of this subject is undeniable as more and more people are fighting for their rights, and nothing is more appropriate than leading discussions and sharing ideas within a learning environment. Therefore, the discipline English with focus on writing and correction allowed the students to relate this theme to their daily life experiences through the English language here and how.

By the end of the discipline, we realized that indeed our students were engaged due to the fact that they were exposed to a theme which they could relate to. In this sense, the majority of them participated actively in the discussions proposed in class; they tried to contribute not only with personal experiences, but also with reports of cases that appear on Brazilian and international media. Taking into account that the focus of the discipline was writing practice, we tried to provide enough resources for the students to enhance this skill by giving them the opportunity to write in class and outside of it. We made this decision mainly because, at first, we felt the students were not confident enough to write in English. So we needed to work a lot on comprehension tasks in order to build their confidence and show them they could express themselves through English. At the end, we saw a great improvement not only in terms of writing abilities, but also in terms of their self-reliance.

It is worth mentioning that other teachers could rely on this material and use it in their classes. Although this project was designed for B1 students, this unit could easily be adapted according to any proficiency level. Moreover, this topic could be expanded to be applied in a context with a greater amount of class hours.

\section{REFERENCES}

BARBOSA, M. C. S. Por que voltamos a falar e a trabalhar com a Pedagogia de Projetos. Projeto-Revista de Educação: projetos de trabalho, 3(4), p. 8-13, 2004.

HERNÁNDEZ, F. Os projetos de trabalho: um mapa para navegantes em mares de incertezas. Projeto - Revista de Educação: Projetos de trabalho, v. 3, n. 4, p. 2-7, 2004.

LANTOLF, J. Sociocultural theory and second language learning. Oxford: Oxford University Press, 2000.

NUNAN, D. (2004). What is task-based language teaching?. In D. Nunan, Task-based language teaching. Cambridge: Cambridge University Press, p. 1 - 18, 2004.

PINTER, A. Some benefits of peer-interaction: 10-year-old children practising with a communication task. Language Teaching Research, 11 (2), p. 189 - 207, 2007. 
RIO GRANDE DO SUL (Estado). Secretaria de Educação do Estado. Departamento Pedagógico. Referenciais Curriculares do Estado do Rio Grande do Sul: Linguagens, códigos e suas tecnologias. Volume I. Porto Alegre, 2009. Disponível em: $<$ http://www.educacao.rs.gov.br/pse/html/refer_curric.jsp?ACAO=acao1> Acesso em: 12 março 2017.

SCHLATTER, M. O ensino de leitura em língua estrangeira na escola: uma proposta de letramento. Calidoscópio, v. 7, n. 1, p. 11 - 23, 2009.

VYGOSTSKY, L. A formação social da mente. São Paulo: Martins Fontes, 1984.

\section{AS AUTORAS}

Larissa Goulart da Silva é Mestre em English Language Teaching pela University of Warwick (Inglaterra) e graduada em Letras - Licenciatura em Português e Inglês pela Universidade Federal do Rio Grande do Sul. Foi professora durante dois anos no Programa Idiomas sem Fronteiras - UFRGS.

E-mail: goulart.larissa@hotmail.com

Marine Laísa Matte é Graduanda do curso de Letras - licenciatura com ênfase nas Línguas Portuguesa e Inglesa na Universidade Federal do Rio Grande do Sul. Atualmente é professora no Programa Idiomas sem Fronteiras - UFRGS.

E-mail : marine.laisa@gmail.com 